\title{
Performance Evaluation of Mono Crystalline Silicon Solar Panels in Khairpur, Sind, Pakistan
}

\author{
Shah; Sadiq Ali* and Sanjrani; Ali Nawaz \\ Department of Mechanical Engineering, Mehran University of Engineering and Technology, Shaheed Zulfiqar Ali Bhutto Campus, Khairpur, Pakistan
}

Submitted: July 20, 2017; Published: August 09, 2017

*Corresponding author: Shah, Sadiq Ali, Department of Mechanical Engineering, Mehran University of Engineering and Technology, Shaheed Zulfiqar Ali Bhutto Campus, Khairpur, Pakistan, Email: ssssadiqalishah@gmail.com

\section{Abstract}

Strength, space, weight, environmental impact, thermal conductivity and cost are important dimensions of the engineering materials. Therefore research is carried out at various levels in academics and industry to improve certain properties of materials to improve their performance, in terms of increase in their efficiency, decrease in weight, decrease in costs and increase in heat resistance. These trends are also visible in silicon solar panel materials on basis of their performance. This article presents the performance efficiency of mono crystalline silicone material solar panel in various parts of the day and periods of the year for a proposed site at Khairpur, Sind, Pakistan.

\section{Introduction}

Materials composition plays a vital role in the performance of various types of processes. Discovery of silicon followed its utilization as an important engineering material due to its capability to produce photo voltaic effect, an important solar energy conversion process. Its use has increased due to its capability of being an environmental friendly energy generation and conversion process.

Solar energy utilization is considered an important energy generation process in the solar rich countries of the world because of its ability to cope up with energy scarcity and availability of an alternative form of energy. Therefore solar energy utilization processes are widely used in developed, developing and under developed solar rich countries. Pakistan is also one of a solar rich developing Countries. There is a huge solar potential, which can be utilized for electrical power generation, water treatment and heating or cooling of the buildings at small, medium and large scale [1-3].

Due to lack of traditional energy sources infrastructure in various areas certain categorization of communities exist on basis of their access level to available energy resources [4]. Human development index represents such population categories on basis of amount of energy consumption.

Since silicon materials are used in solar photo voltaic cells these can contribute to sustainable and efficient solar energy generation processes in those areas, which are still suffering from unavailability of traditional energy infrastructure. Solar photo voltaic energy generation process can facilitate the development of energy infrastructure to such, areas, which have still access to basic amenities like electricity and water $[2,5,6]$.

\section{Methodology}

In order to analyze scale of solar energy utilization in any solar rich area it is necessary to estimate expected solar energy potential. Likewise,an effort was made to estimate solar energy generation capability using silicon mono crystalline solar photo voltaic cell panels at a proposed site in Khairpur, Sind, Pakistan.

Available solar radiation climatic online data is used for estimation of energy potential with the help of Ret Screen software. The data so obtained is processed for analysis and is interpreted in tables and graphs.

\section{Results}

The results reveal that considerable amounts of heat and electrical energy can be generated using silicon mono crystalline solar photo voltaic panels at Khairpur, Sind, Pakistan. However, there is variation in the energy generation process because of the reason that solar energy amounts received variably variably round thehours of day and the months of year at the proposed site. It also reveals that the amount of energy generated is more in the noon hours and in the summer season than other hours of the day and seasons of the year at the proposed site. Therefore, 
it is possible to utilize efficiently silicon mono crystalline solar photo voltaic cells for energy conversion processes at the proposed site. The results are presented in Table 1 and Figure 1.

Table 1: Annual Solar Irradiance Data [4].

\begin{tabular}{|c|c|c|c|}
\hline S.No & Month & $\begin{array}{c}\text { Solar Irradiance } \\
\qquad\left(\mathrm{kWh} / \mathrm{m}^{2} / \mathrm{d}\right)\end{array}$ & $\begin{array}{c}\text { Solar Irradiance } \\
\left(\mathrm{W} / \mathrm{m}^{2} / \mathrm{d}\right)\end{array}$ \\
\hline 1 & January & 3.97 & 165.4166667 \\
\hline 2 & February & 4.78 & 199.1666667 \\
\hline 3 & March & 5.44 & 226.6666667 \\
\hline 4 & April & 6.25 & 260.4166667 \\
\hline 5 & May & 6.64 & 276.6666667 \\
\hline 6 & June & 6.73 & 280.4166667 \\
\hline 7 & July & 6.21 & 258.75 \\
\hline 8 & August & 5.81 & 242.0833333 \\
\hline 9 & September & 5.66 & 235.8333333 \\
\hline 10 & October & 4.99 & 207.9166667 \\
\hline 11 & November & 4.12 & 171.6666667 \\
\hline 12 & December & 3.64 & 151.6666667 \\
\hline
\end{tabular}

Figure 1: Annual solar irradiance in $\mathrm{kWh} / \mathrm{m}^{2} / \mathrm{d}[4]$.

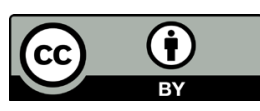

This work is licensed under Creative Commons Attribution 4.0 Licens DOI: 10.19080/JOJMS.2017.02.555591
The results are promising for energy generation and conversion process in such traditional energy deficient and solar energy efficient areas of Khairpur, Sindh, Pakistan and proposed silicon mono crystalline cell solar photovoltaic energy generation system are capable to provide required amounts of energy to cater electrical power generation and water treatment processes needs of the communities living in such underdeveloped areas.

\section{Conclusion}

It has been found that Silicon mono crystalline solar photovoltaic materials based solar panels may produce more photovoltaic effects at ambient temperature around 20-26 degree Celsius at noon in May to August in a de centralized, selfcontained, independent and environmental friendly manner in underdeveloped areas of Khairpur and in vicinity of Khairpur, Sind, Pakistan.

\section{References}

1. Shah, S.A, Zhang Y (2010) Prospects of Coastal Solarisation for Freshwater and Electricity Production. ISESCO Science and Technology Vision 6(10): 82-87.

2. Shah, S.A, Abbasi AF, Daudpoto J (2013) Case Study of Electrical Energy Requirement for meeting various needs in a desert dwelling. Mehran University Research Journal 32(3).

3. Shah, S.A, Syed Ahmed Z, Faraz SF, Asadullah B (2015) Prospects of utilization of modified dish type solar cooker in rural areas of Sind, Pakistan. Australian Journal of Engineering and Technology Research 2(1).

4. Shah, S.A, Khatri, K.L, Solangi, G.S., Lanjar,A.G, Sanjrani, A.N. (2016) Lack of energy infrastructure and its effects on living standards in underdeveloped areas of Sind. Science International Lahore 28(5).

5. Sadiq, Edwards,R. (2011) Sustainable energy generation processes in the deserts of solar-rich countries International Journal of Sustainable Energy 32.

6. Shah, S.A, Rafique S, Jumani MS (2014) Prospective study of solar energy as a sustainable energy source of electrical power generation. Sind University Research Journal (SURJ) 46(4).

\section{Your next submission with Juniper Publishers} will reach you the below assets

- Quality Editorial service

- Swift Peer Review

- Reprints availability

- E-prints Service

- Manuscript Podcast for convenient understanding

- Global attainment for your research

- Manuscript accessibility in different formats

( Pdf, E-pub, Full Text, Audio)

- Unceasing customer service

Track the below URL for one-step submission https://juniperpublishers.com/online-submission.php 